\title{
The Standards in Admitting Expert Evidence in Ethiopia: Some Practical Discrepancies
}

DOI http://dx.doi.org/10.4314/mlr.v11i1.9

\section{Abstract}

Abreha Mesele Zinabu *

Judges render justice based on the presented evidence justifying their decisions. In criminal cases, these decisions can have ramifications on an individual's right to liberty, life and property. Correctness of conviction much depends on the evidence presented to the courtroom and the interpretation of the evidence by judges. Expert evidence is particularly important because certain issues are beyond the expertise of judges in the current era of specialization and due to everexpanding advances in technology. Expert evidence has to be used very cautiously based on a set of objective criteria that judges can use. This comment looks at the experience of other countries in relation to admission of expert evidence. It then assesses the current practice in Ethiopia by looking at a few cases and concludes that there is wide variation in admitting expert evidence and regarding the weight given to it by different courts.

\section{Key terms}

Expert Evidence, admission, weight of evidence, criminal justice administration, Ethiopia

\section{Introduction}

Expert witness is indispensable for the proper functioning of the criminal justice system. However, judges may sometimes be unsure about the procedures for admitting it and the weight that should be attached to it may be sometimes problematic to judges. Wrong convictions may ensue as a result of problems with scientific uncertainties on the side of psychologists and other behavioral science scholars. Expert testimony by such experts serves two principal goals: inform judges that eyewitnesses are significantly less reliable than common

\footnotetext{
* Abreha Mesele Zinabu, LLB Mekelle University, LLM in Human Rights Law Addis Ababa University, and Lecturer, Mekelle University, School of Law Email: expansion97@gmail.com.
} 
sense suggests, and also should educate judges about the nature of human memory and specific variables that affect the accuracy of identifications. ${ }^{1}$

In Ethiopia, judges may request expert evidence in criminal proceedings when they find that the evidence presented creates doubt. Professionals, on the other hand, are obliged (under article 448 of the FDRE Criminal Code) to aid justice and experts cannot generally refuse to testify. However, the admissibility, relevancy and weight of expert testimony may vary from case to case. Expert testimony as it relates to "definite scientific findings" is binding on judges in cases of assessing criminal responsibility and deciding on the sentence of young criminals. $^{2}$ The legal inference is left to courts taking the expert testimony into account. In evaluating the findings of expert witness, the judge may find it difficult to distinguish between personal appreciations and definite scientific findings.

Ethiopia has its law of evidence scattered in the various codes including the Civil Code of 1960, Criminal Code of the 2004, Criminal Procedure Code of the 1961, Civil Procedure Code of the 1965 etc. The scattered procedural rules of evidence in the various codes are vague, incomplete/incomprehensive or difficult to apply by courts. The Expert evidence is not different from the problems of other types of evidence. Expert evidence in Ethiopia is particularly problematic due to the advancement of technology and other scientific theories/pedigree.

The first section of this comment highlights the legal framework of expert evidence in Ethiopia followed by the burden of proof in criminal cases in Section Two. The third and fourth sections briefly state some experience in admitting expert evidence and standards for admitting expert evidence in Ethiopia. The last section highlights experiential safeguards against expert evidence.

\section{Legal Framework of Expert Evidence in Ethiopia}

Article 20(3) FDRE Constitution cum article 23(4) and article 57(1) of the FDRE Criminal Code clearly indicates that every person is presumed innocent until proven guilty. It is also further articulated under article 24 of the Criminal

${ }^{1}$ Daniel A. Bronstein. (2012), Law for the Expert Witness. Taylor and Francis Group, LLC, $4^{\text {th }}$ ed.

2 The FDRE Criminal Code, Proclamation No. 414/2004, Art. 51/3 "On the basis of the expert evidence the Court shall make such decision as it thinks fit. In reaching its decision it shall be bound solely by definite scientific findings and not by the appreciation of the expert as to the legal inferences to be drawn therefrom." Art. 54/3 contains a similar provision as regards expert testimony in assessing the sentence of young criminals (aged between 9-15). 
Procedure Code that the investigating police officer shall keep all relevant evidences recorded. Moreover, article 42(1)(a)) clearly indicates the importance of evidence including expert evidence, against conviction where the public prosecutor $^{3}$ is prohibited from instituting a charge if there is no sufficient evidence to justify conviction.

The word expert witness, in Ethiopian legal framework, is understood as a natural person who is knowledgeable, having specialized knowledge, expert, trained, wise, educated, professional and skillful respectively). ${ }^{4}$ The expertise of the witness involves specialized knowledge and training outside the common sense or knowledge of judges. The expert witness may provide his/her testimony before the court or send his/her finding as a report to the court requesting it. However, there is no clear provision as to when the court can ask the physical appearance of the expert. Article 136(2) cum 142(2) second alinea of the Criminal Procedure Code of Ethiopia clearly indicates that the public prosecutor shall call his/her witnesses and experts, if any, and the witnesses and experts shall be sworn or affirmed before they give their testimony. From this, it can be deduced that expert witnesses should appear before the court for testimony; the Code is silent about expert report.

\section{Burden of Production and Degree of Proof in Criminal Cases}

The public prosecutor, in Ethiopia, has the burden to prove his/her allegations beyond reasonable doubt by producing any relevant direct or indirect evidence as per articles 134(2) of the Criminal Procedure Code cum article 20(3) of the FDRE Constitution. ${ }^{5}$ However, there are crimes in which the burden would shift to the suspect. ${ }^{6}$ Expert evidence may be produced: (a) by accused persons (or their advocates for their defences), or (b) by public prosecutors to prove their

\footnotetext{
${ }^{3}$ The public prosecutor should prove the elements of crime: the legal element, material element and moral or mental element as per article 23(2) and (4) and article 48(1) cum 57(1) of the FDRE Criminal Code 2004 beyond reasonable doubt and article 130(1(g)) of the Criminal Procedure Code of the Empire and article 14(2) of the ICCPR and General Comment No. 13 on Issues of Criminal Proof and Degree of Proof.

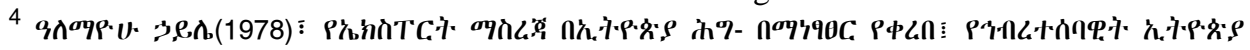

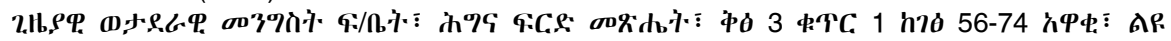

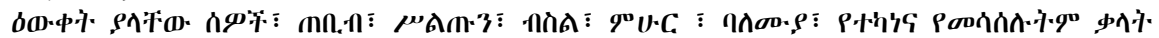
entoma ::

${ }^{5}$ But the Supreme Court in its Cassation Bench under Cassation No. 104923 provides that the burden of proof is not beyond reasonable doubt but clear and convincing which is binding by the virtue of proclamation no.454/2005.

6 Ethiopian Criminal Justice Policy 1997 in crimes of corruption, Concerted Crimes, Terrorism which are heinous by their nature to the public at large.
} 
allegation $^{7}$ or (c) by judges before or during the proceedings. The production of evidence including expert evidence should meet the parameter of relevancy to be admissible.

\section{Experience of Other Countries in Admitting Expert Evidence}

Fundamental condition of admissibility is that evidence must be relevant. ${ }^{8}$ That means it must be capable of rationally influencing the assessment of facts in issue (i.e., the contested or material facts). Admission of expert evidence depends on the application of the following criteria:

(a) Relevance: On behalf of the Court, Justice Sopinka explained that relevance is a broad inquiry, encompassing logical as well as legal relevance, and requiring a trial judge to assess the reliability of the putative evidence against its costs, including the risk of distortion or overvaluation;

(b) Necessity in assisting the trier of fact: Necessity was described as a standard that is higher than the "helpfulness" requirement set out in English precedent, but that should not be judged "by too strict a standard";

(c) The absence of any exclusionary rule; [and]

(d) A properly qualified expert: ${ }^{9}$ The qualification requirement was described by Sopinka as a need for the expert to demonstrate "special or peculiar knowledge [acquired] through study or experience". ${ }^{10}$ The expert witness must have undergone training (and received appropriate qualifications or certification) or have experience, and the opinion should be derived from a recognized "body of knowledge" (or "field") or experience. ${ }^{11}$

An expert's opinion is admissible to furnish the court with scientific information which is likely to be outside the experience and knowledge of a judge or jury. If

\footnotetext{
${ }^{7}$ for the interest of justice as per articles 142(2) second alinea of the Criminal Procedure Code of the Empire, 136(2) second alinea of the same code and 143(1) cum article 149(1) of the Criminal Procedure Code of the Empire respectively.

${ }^{8}$ James Bradley Thayer. (1898). A Preliminary Treatise On Evidence at the Common Law 485. As cited in Gary Edmond, Simon Cole and et al. (2013). Admissibility Compared: The Reception of Incriminating Expert Evidence (i.e., Forensic Science) in Four Adversarial Jurisdictions. University of Denver Criminal Law Review, Vol. 3, pp 31-109

${ }^{9}$ This is all about competence where it incorporates both the relevance of the qualification and the capability of the expert to provide the expert testimony. For example, the expert should have the sound mental capacity, as in any other witness, the expert should not be prohibited by law or the expert's public rights should not be taken away by punishment.

${ }^{10}$ Gary Edmond, Simon Cole and et al. (2013). 'Admissibility Compared: The Reception of Incriminating Expert Evidence (i.e., Forensic Science) in Four Adversarial Jurisdictions.' University of Denver Criminal Law Review, Vol. 3, pp 31-109.

11 Ibid.
} 
on the proven facts a judge or jury can form their own conclusions without help, then the opinion of an expert is unnecessary. ${ }^{12}$ (Italics added)

This principle emphasizes that courts should not demand expert evidence if the disputed fact can be addressed by the common knowledge of judges. However, different standards of tests have been utilized for the admission of expert evidence in two different very well-known landmark American cases: Frye v. United States (1923) and Daubert v. Merrell Dow Pharmaceuticals, Inc. (1993). In Frye, courts were required to admit scientific evidence only as long as it was generally accepted by the scientific community.

Accordingly, experts were expected to explain why and how their work met the test of general acceptance. But the problem comes when the expert opinion deviates from the concept of scientific community irrespective of the merit of the expert's finding. Hence, experts should be bound only to the existing body of knowledge because introducing a new concept or theory demands the acceptance of the larger scientific community for possible acceptance by the judiciary. Thus, under Frye, emerging sound science that might have been of greater assistance to a jury was excluded. ${ }^{13}$ This approach puts limits on accepting new developments in science.

Contrary to Frye, in the case of Daubert, judges were given a certain degree of flexibility in their determination to admit or reject expert testimony. A judge, in the Daubert case, is expected to inquire in some detail as to substance of those methodologies. A judge can exclude expert opinions as long as she or he does not "abuse discretion". ${ }^{14}$ The focus in Daubert case is not the conclusion of the expert but the principles and methodologies of the expert to arrive at the conclusion and the conclusion and other aspects are left to the discretion of the court.

The Daubert test has also been criticized for requiring the judiciary to evaluate the merits of scientific theories or practices, a task for which it is not properly qualified - and the reason why expert testimony is required in the first place! This in turn may produce false conviction as it enables judges to evaluate issues for which the court is not properly qualified. Shortly after Daubert, the US Supreme Court decided two other cases; General Electric v. Joiner (1997) and Carmichael v. Kumho Tire Company (1998) which shaped the way courts

${ }^{12}$ R. v. Turner, [1974] QB 834 (England.), as cited in Gary Edmond, Simon Cole and et al. (2013). 'Admissibility Compared: The Reception of Incriminating Expert Evidence (i.e., Forensic Science) in Four Adversarial Jurisdictions'. University of Denver Criminal Law Review, Vol. 3, pp. 31-109.

${ }^{13}$ Jack v. Matson. (2013). Effective Expert Witnessing: Practicing for $21^{\text {st }}$ Century. $5^{\text {th }}$ edition. Taylor \& Francis Group, LLC, pp. 23-25.

${ }^{14}$ Id., pp. 14-16. 
evaluate expert evidence and expand the scope of Daubert to all experts, rather than only experts on scientific matters.

There is a growing tendency that in the majority of criminal cases, judges trust expert witnesses and tend to apply expert testimony without any further scrutiny. William O'Brian commented that "virtually all of the areas of 'forensic science', with the exception of DNA evidence, have quite dubious scientific pedigrees". ${ }^{15}$ Likewise, Judge Andrew Gilbart QC, stated that he is often struck by "how poor some suggested scientific evidence is in criminal trials", adding that he is also frequently struck by "how ill equipped advocates are to challenge it when they have no experts of their own to advise them". ${ }^{16}$

\section{Standards for Admitting Expert Evidence in Ethiopia}

Relevancy is a prerequisite for the admission of evidence by courts; however, certain relevant evidences may not be admissible for reasons of exclusion ${ }^{17}$ due to public policy and liberty of individuals. Moreover, the expert should be competent. ${ }^{18}$ This requirement of competence of expert witnesses is equally applicable to evidence that is obtained through coercion in violation of Article 19(6) second alinea of the FDRE Constitution.

Another issue in the standard of admitting expert evidence emanates from the unique nature of expert evidence despite the fact that there is no clear stipulation of these criteria under the law other than the experience of courts. The first requirement for the admissibility of expert evidence is that the expert should provide evidence which cannot be discovered by common sense/knowledge. The second requirement is that the expert's finding must be supported by the scientific community. ${ }^{19}$ As discussed earlier, the result of the expert witness must be processed by modern scientific theories, research methods, and technologies. But consideration must be given to the changing aspects of scientific researches and methods across time. Therefore, there can be differences among professionals but as long as expert finding does not

\footnotetext{
${ }^{15}$ Ibid.

${ }^{16}$ The Law Commission, Crown (2011). Expert Evidence in Criminal Proceedings in England and Wales. Law COM No. 325.

17 Article 19(6) of the FDRE Constitution.

${ }^{18}$ Competence is not all about knowledge and training of the expert but also about the experts mental or any other kind of capacity, there should not be prohibition as a consequence of criminal violation as in article 123(a) cum article 448 of the FDRE Criminal Code and article 196 of the Civil Code of Ethiopia.

19 Fred C. Inbau (1935), Scientific Evidence in Criminal Cases. Law and Contemporary Problems, Vol.2 , p. 501 as cited in 9.

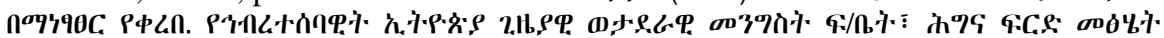
ศ:/
} 
contravene the central pillars of accepted theories and does not deviate sharply from the normal understanding, the finding of an expert will be considered.

The weight of evidence attached to expert evidence in particular and evidence in general, in Ethiopia, is not adequately regulated. The weight of evidence attached to expert evidence is only cited in the investigation of mental status $^{20}$, age and sentencing and other measures that courts take in relation to a convicted person as indicated under legal provisions such as articles 51, 54 and 116(3) of the FDRE Criminal Code. In cases of determining criminal irresponsibility and of deciding on measures applicable to young criminals, expert evidence will be mandatory for judges to admit where the outcome of the investigation is scientifically definite. However, personal appreciation stated by the expert and the results obtained that are not scientifically definite may be accepted or rejected based on the discretion of judges as clearly stipulated under article 51(3) cum 54(3) of the FDRE Criminal Code. In reaching its decision, the Court shall be bound solely by definite scientific findings ${ }^{21}$ and not by the appreciation of the expert as to the legal inferences to be drawn. (Emphasis added)

Courts in Ethiopia remain unsure about the weight and other aspects of expert evidence because the laws are not adequately comprehensive. In effect, courts have resorted to the experience of other countries to decide the admission of expert evidence. The Supreme Court in relation to this issue provides in the case of (h)+

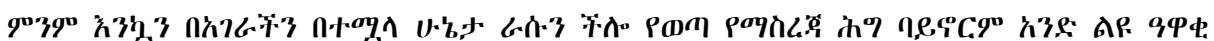

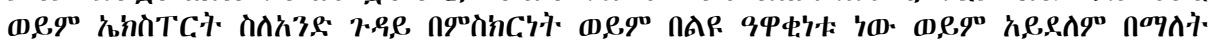

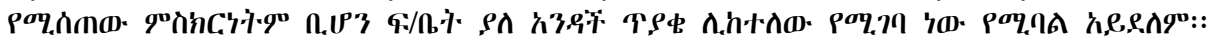

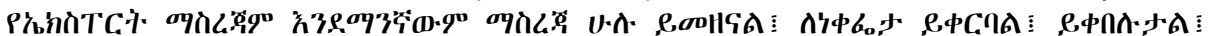

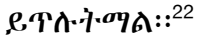

The weight of expert evidence depends on the discretion of courts. Courts may use expert evidence either as corroborative or conclusive. It should be noted that courts are not at liberty to arbitrarily reject or accept expert evidence, but they should rather respect the laws as per article 149(1) of the Criminal Procedure Code which requires them to attach reason for their decision. However, courts tend to be hasty in automatically admitting expert evidence. This may, for example, infringe the Constitutional right of the accused to defend

\footnotetext{
${ }^{20}$ Article 48 cum 49 of the FDRE Criminal Code.

${ }^{21}$ However, it is difficult to judges to evaluate scientific definite findings which demands knowledge other than the legal knowledge as in Daubert case. The degree of difficulty of

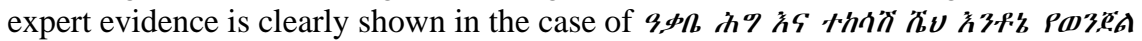

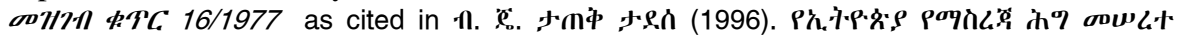

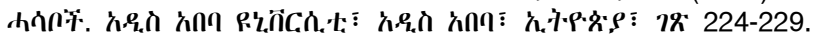

22 9.

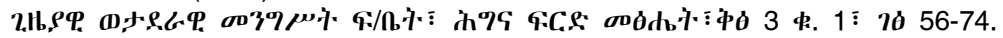


and confront any opposing evidence. ${ }^{23}$ On the contrary, courts sometimes restrict the submission of evidence by parties to defend their cases merely because the court has ordered expert evidence. ${ }^{24}$ The Federal Supreme Court of Ethiopia, in its Cassation No. $92141^{25}$ and $62041^{26}$ has provided that expert evidence should not be automatically accepted but (like other evidence) it should be evaluated and assessed by courts using different criteria.

\section{Safeguards against Expert Evidence}

Ethiopian courts use various mechanisms to assess the credibility and validity of expert evidence which include cross-examining the expert, re-evaluating the expert evidence by another expert, seeking expert evidence to be verified by a board decision, and demanding help from professional associations to which the expert is member. Cross-examination, for example, can evaluate the credibility and validity of expert testimony but this only applies to experts who provide oral testimony before a court. However, most Ethiopian courts receive expert evidence in the form of report where cross-examination is impossible. Yet, the law clearly indicates that expert witness will provide his/her testimony after taking oath as per article 136(2) second alinea cum 142(2) second alinea of the Criminal Procedure Code.

Reevaluation by another expert is also a mechanism that is used by courts to examine expert evidence which is doubtful. According to article 143(1) of the Ethiopian Criminal Procedure Code, courts can call any witness including expert witness in the interest of justice. However, subjecting expert evidence to another expert for ascertaining its validity and reliability should be taken very cautiously not to defeat the Constitutional right to speedy trial under article 20(1) first alinea of the FDRE Constitution.

\footnotetext{
23 Article 20(4) of the FDRE Constitution.

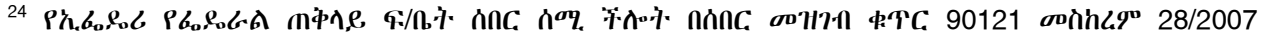

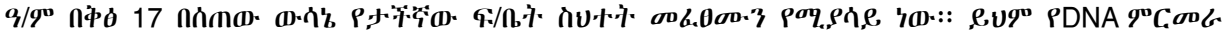

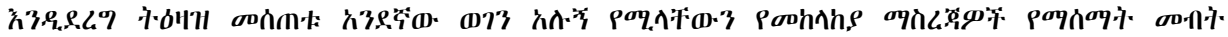

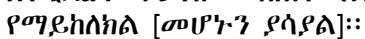

25 לз.

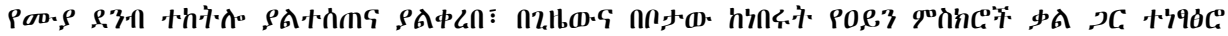

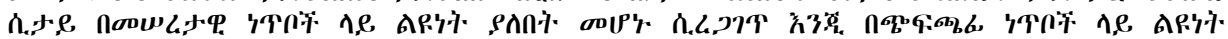

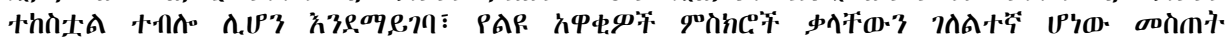

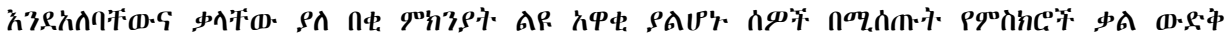

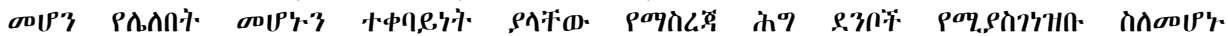

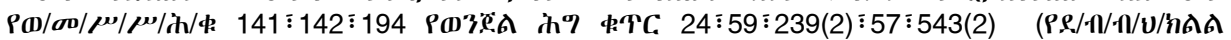

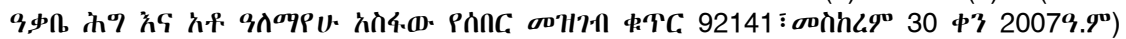

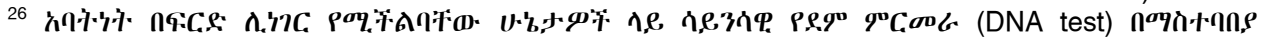

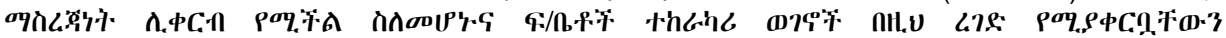

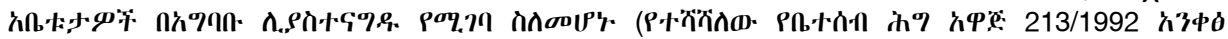

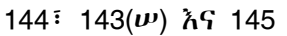


As mentioned above, failure to testify truthfully and refusal to aid justice can entail criminal sanction. This is in addition to civil liabilities ${ }^{27}$ and administrative liabilities which can be imposed upon a professional who has failed to discharge his/her duty, in compliance with the moral standard of the profession.

Courts may also use professional associations while recruiting an appropriate expert for inquiry. This can ensure the requisite professional standards in expert services thereby serving the interest of justice. Moreover, collective investigation by using board decisions in expert evidence can reduce the risks of bias and corrupt practices, in effect, increasing reliability and validity in expert evidence.

\section{Conclusion}

Justice administration organs in general and judges in particular have developed the habit of accepting expert evidence as conclusive without further scrutiny of its relevancy, materiality and validity. In criminal cases, for example, this can violate the fundamental due process rights including fair trial, the right to defend and confront opposite witness to the suspect. This in turn affects the quality of justice aspired by the FDRE Constitution.

Another issue of concern relates to taking expert evidence as documentary evidence where the weight of evidence hugely varies. Very few judges and public prosecutors consider expert evidence solely as oral evidence which can be subjected to oral examination to effectively evaluate the testimonies of expert witnesses.

Furthermore, there is a clear inconsistency between the existing laws of expert evidence and the practice in verifying, weighing and admitting expert evidence. Therefore, courts should be cautious, and it is only oral evidence that can be considered as expert evidence. Equally important is the need for rules on expert evidence which is long over due.

${ }^{27}$ Article 2031, 2130 cum article 2028 of the Civil Code of the Empire 